\title{
Effect of Organizational Justice, Trust in Bosses and Job Satisfaction on Employee Performance at PT. PLN (Persero) Main Unit of West Sumatra Region
}

\author{
Marco Arief Juarsah ${ }^{1}$, Erni Masdupi ${ }^{2}$, Syahrizal ${ }^{3}$ \\ ${ }^{1}$ Universitas Negeri Padang, Padang, Indonesia, $\square$ marco.ariefjuarsah@gmail.com \\ ${ }^{2}$ Universitas Negeri Padang, Padang, Indonesia, $\square$ ernimasdupi@fe.unp.ac.id \\ ${ }^{3}$ Universitas Negeri Padang, Padang, Indonesia, $\bowtie$ syahrizal@fe.unp.ac.id
}

\begin{abstract}
The most important thing in an organization is performance. Performance is the goal of the organization. Performance is a measure of the success of an organization in carrying out business processes. In this article we have developed the influence of Organizational Justice, Trust in Boss and Job Satisfaction with Performance From relevant theories and research conducted by several researchers about the relationship between these variables in previous studies, we argue that Organizational Justice has a significant effect on Satisfaction Work. Significant Trust in Bosses for Job Satisfaction. Organizational Justice has a significant effect on performance. Trust in bosses is significant for performance. Job Satisfaction has a significant effect on performance.
\end{abstract}

Keywords: organizational justice, trust in boss, job satisfaction, performance

\section{Introduction}

Performance is the result of work that is successful in the assignments given, assignments given on skills, experience and sincerity with time (Hasibuan, 2012: 94). Company performance measurement is designed to assess how activities improve performance and the final results achieved.This Research. improving performance is an important part of a company because performance is a measure of the success of a company. As one of the part of measure of the success company, performances must be improve. Related to increase performance, the problem is how to increase performances.

Phenomena related to research occur at PT. PLN (Persero) Main Unit of West Sumatra Region. Based on performance and interviews with several employees of PT. PLN (Persero) The Main Unit of the West Sumatra Region has decreased. For example in 2015 - 2016, the performance of PT. PLN (Persero) The Main Unit of the West Sumatra Region has decreased. Seen in the results of employee performance evaluations conducted by PLN in sequence in 2015 to 2016 in all aspects was $74 \%$ and $71.5 \%$.

Based on the results of PLN's internal assessment, building performance is important thing and to build it is not an easy thing because there are so many factors that influence performance including organizational justice, trust in superiors and job satisfaction.

Based on this phenomenon, The Researcher interest to research with tittle " Effect of Organizational Justice, Trust in Bosses and Job Satisfaction on Employee Performance at PT. PLN (Persero) Main Unit of West Sumatra Region"

The Objective of the research :

1. to determine the influence of organizational justice on job satisfaction of employees of PT. PLN (Persero) Main Unit of West Sumatra Region.

2. to determine the influence of trust in Boss on job satisfaction of employees of PT. PLN (Persero) Main Unit of West Sumatra Region.

3. to determine the effect of organizational justice on the performance of employees of PT. PLN (Persero) Main Unit of West Sumatra Region.

4. to determine the influence of trust in superiors on the performance of employees of PT. PLN (Persero) Main Unit of West Sumatra Region. 
5. to determine the effect of job satisfaction on the performance of employees of PT. PLN (Persero) Main Unit of West Sumatra Region.

\section{Theoretical Review}

\section{Performance}

Performance is the ability achieved and desired from the behavior of employees in carrying out work which is the responsibility of individuals or groups. Sinambela's opinion (2016: 480) regarding performance is the ability of employees to do certain skills and how far their ability to carry out tasks assigned to them. Moeheriono (2014: 95) expressed the opinion of performance as the level of achievement of an activity program or policy in realizing the goals, objectives, vision and mission of the organization as outlined through the organization's strategic planning.

Mangkunegara Statement (2014: 9), regarding employee performance is the work result in the quality and quantity achieved by an employee in carrying out his duties in accordance with the responsibilities given to him. Sari, et al (2016) argue that performance as a result of the work process at a certain time and place in a planned manner carried out by employees and organizations concerned.

Employee performance is employee behavior or actions related to the goals or objectives of the organization concerned (Qatmeemalmarhoon, et al, 2017). Employee performance is the result of work in quality and quantity achieved by an employee in carrying out his duties in accordance with the responsibilities given to him.

According to Armstrong and Baron (2005: 9) individual performance is influenced by personal factors (skills, self-confidence, motivation and commitment), leadership factors (quality manager / group leader in providing encouragement, guidance and support), team factors (co-worker quality support), systemic factors (work systems and facilities provided by the organization), and situational factors (changes and pressures from the internal and external environment).

In the opinion of Mangkuprawira and Hubeis (2007: 153), the factors that influence employee performance consist of: Intrinsic factors, among others, Personal or individual factors, namely knowledge, skills (skills), ability, confidence, motivation, job satisfaction and commitment owned by each individual employee in the organization.

\section{Organizational Justice}

Organizational justice is the perception of fair treatment obtained by employees of the organization. Robbins (2015: 145) states that organizational justice is a general description of the perceptions or thoughts about justice that apply where they work.

Another definition says that organizational justice is an individual's perception of justice from decisions made by his superiors (Kristanto, 2015). Gibson, et al. (2012) define organizational justice as a level at which an individual feels treated equally in the organization where he works. Another definition says that organizational justice is a fair perception of a person towards decisions taken by him (Colquitt et al., 2009).

Organizational justice is a perception where employees feel treated fairly in work (Retno et al., 2014). In line with that view, Mahdani, et al (2017) define organizational justice as employees' perceptions of their treatment in fair and honest organizations. So, organizational justice concerns how employees see justice at work. According to Siti and Tri (2013: 95) salaries are payments received by employees monthly, weekly, or every hour as a result of their work. Whereas according to Suwatno and Priansa (2013: 232), salary is a substitute for services that have been provided by workers in their jobs.

Al-Zu'bi's research (2010) says that organizational justice indicators include:

1. Distributive justice refers to the justice felt by respondents based on the results they receive from the organization. 
2. Procedural justice refers to the justice felt by respondents from a rule and procedure that regulates a process within an organization.

3. Interactional justice refers to the justice felt by employees towards the treatment of leaders to employees such as when leaders treat employees with respect and dignity.

\section{Trust in Boss}

Trust becomes a very important thing because it has implications for the performance of employees who lead them to do the work they want in accordance with certain objectives set first. Organizing trust is important because this will help regulate complexity, develop action capacity, enhance collaboration and improve organizational learning capabilities. According to Robbins and Judge (2014: 388) trust is the main attribute associated with leadership, ignoring it can cause serious side effects on group performance. Mahdi (2008: 160) states, trust in superiors is an attitude of not hesitating from an employee to his boss over the policies made by the boss.

Hajar et al (2018) argue that trust is a belief in a person's integrity, ability, character or something. Another opinion, Becerra et al (2011) trust is an assessment of a person's relationship with another person who makes a particular transaction. Opinion of Krot and Lewicka (2012) trust is an important part of professional relations between coworkers, between managers and employees, or between employees and managers. Trust is an invaluable intangible asset in the organization to produce high performance. Another opinion regarding trust, Orebiyi (2011) regarding trust in superiors shows the extent to which subordinates react to the support provided by leaders.

Yulianti (2015: 287) defines trust as a feeling of self-confidence possessed by employees or employees that at times when facing uncertain or risk situations the leadership's behavior and words show consistency and are very helpful. Robbins and Judge (2014: 99) have the idea that working at a boss must have honesty. This is needed to convince employees / subordinates that their boss are indeed worthy to be made leaders and deserve to gain trust

From the opinions above, it can be concluded that trust in boss is the attitude of trust possessed by employees of their boss with the assumption that their superiors have high honesty and are worthy of being made as a leader in the company.

\section{Job Satisfaction}

Kreitner and Kinicki (2014: 169) define job satisfaction as an affective or emotional response to various aspects of one's work. There are consequences when employees like their jobs, and there are consequences when employees don't like their jobs. The definition of job satisfaction shows two related concepts, namely the tendency of an employee to be satisfied or less satisfied with the results of his work which consists of self-employment, salary, recognition, conditions, colleagues, organizational politics (Maria, 2012).

Sunyoto (2012: 26) defines job satisfaction as a pleasant or unpleasant emotional state in which employees see work. Job satisfaction reflects a person's feelings for his job. according to Sopiah (2008: 170) states job satisfaction is a person's emotional response to situation and working conditions. Emotional responses can be feelings of satisfaction or dissatisfaction.

Priansa (2014: 291) job satisfaction is the feeling of employees on their work, whether happy or like, not happy or dislike as a result of employee interaction with their work environment or as a perception of mental attitude, also as a result of employee assessment of their work. Bakhshi et al. (2009) stated that job satisfaction is one of the most widely used variables in organizational justice research. Adigun et al. (2017) state that job satisfaction is very important because its absence often causes lethargy and reduces organizational commitment. 


\section{The Effect of Organizational Justice on Job Satisfaction}

Sutrisna and Rahyuda (2014) state that justice is able to reflect individual appreciation for work and its existence in the organization and from justice will also foster a sense of job satisfaction in the individual. In line with Naeem et al. (2014), it is of the view that every employee wants justice in the work environment, such as fair procedures used in terms of stipulating rewards, sharing benefits and interacting with superiors will make them more satisfied.

Research conducted by Fatimah et al (2011) found that there was a positive and significant effect of organizational justice on job satisfaction. Sethi et al (2013) stated that organizational justice has a positive effect on job satisfaction. The results of this study were also supported by Susanj and Jakopec (2012). The higher the justice felt by employees of the organization, the higher their satisfaction with their work will be.

H1: organizational justice has a significant effect on employment outcomes.

\section{The Effect of Trust in Boss on Job Satisfaction}

Leaders should care about the level of job satisfaction in their organizations for at least three reasons, namely there is clear evidence that unsatisfied employees often skip work and are more likely to resign, the second has been demonstrated that satisfied employees have better health and age longer, and the third is job satisfaction (Robbins, 2014).

Research Siddiqi and Kharshiing (2015) shows that when employees trust their organization, they are more satisfied with their work. Trust is important for employee empowerment which in turn results in greater job satisfaction. In line with the research findings of Meral et al (2016), it was stated that trust positively influences job satisfaction.

H2: Boss Trust has a significant effect on job satisfaction.

\section{The Effect of Organizational Justice on Performance}

Organizational justice has been seen as an important variable that plays a major role in improving employee performance of an organization. Because various studies have shown, if employees are not treated fairly, the results will reduce the output of employees as a natural response to unfair treatment (Iqbal et al., 2017).

In contrast to Iqbal, 2017 found by Mahdani, et al. (2017) organizational justice has a significant effect on the mediating variables of job satisfaction, but does not affect employee performance variables.

H3: Organizational Justice has a significant effect on employee performance.

\section{The Effect of Trust in Boss on Performance}

The attitude of the leader can influence his subordinates, for example on trust, job satisfaction, performance and others. It is realized that there is no single best leadership style that is universally applicable to all situations or environments, so the situational / contingency approach in choosing an effective leadership model is the best alternative answer (Handoko, 2011). Trust in leadership has been linked to high task performance, more citizenship behavior, and positive attitudes towards their work and organization (Colquitt, L 2009).

The research findings of Widjajani, et al (2017) state that trust has a significant influence on Employee Performance. But deferences with Arief, et al (2018) which states that trust in leadership does not have a significant effect on employee performance.

H4: Trust in Boss has a significant effect on performance. 


\section{The Effect of Job Satisfaction on Performance}

Employee performance greatly impacts the maximum performance of the company. That is what causes employee job satisfaction is considered very important especially to support the company's performance in competition in this era of globalization (Wijaya \& Sutanto, 2014: .2). Robbins and Judge (2014: 113) states that organizations that have more satisfied employees tend to be more effective than organizations that have employees who are less satisfied. Whereas according to the same thing also stated by Davis and Newstroom in Sinambela (2016), suggesting that some managers assume that high job satisfaction will forever lead to high achievement.

The effect of job satisfaction on performance is stated by Fadlallh (2015) stating that there is a positive and significant effect of job satisfaction on employee performance. Adigun Research, et al (2017) state that job satisfaction has a significant influence on employee performance.

H5: Significant Job Satisfaction with Performance.

\section{Methods}

This study focused on employees of PT. PLN (Persero) Main Unit of West Sumatra Region. This study aims to analyze the influence of exogenous variables, these variables among them Organizational Justice (X1), Trust in Boss (X2), Job Satisfaction (X3) on endogenous Variabel Performance (Y) employees of PT. PLN (Persero) Main Unit of West Sumatra Region.

The sample in this study uses sample determination using the proportionate stratified random sampling technique because the population has members that are not homogeneous and proportionately structured.

Table 1 The Sample of Research

\begin{tabular}{clcc}
\hline Num. & \multicolumn{1}{c}{ Division } & Sample & $\begin{array}{c}\text { Total } \\
\text { Sample }\end{array}$ \\
\hline 1 & Human Resource Division & $53 / 218 \times 141=$ & 34 \\
\hline 2 & Financial Division & $33 / 218 \times 141=$ & 21 \\
\hline 3 & Business Division & $32 / 218 \times 141=$ & 21 \\
\hline 4 & Distribution Division & $36 / 218 \times 141=$ & 23 \\
\hline 5 & Planning Division & $25 / 218 \times 141=$ & 16 \\
\hline 6 & Safety Work Division & $16 / 218 \times 141=$ & 10 \\
\hline 7 & Procurement Executor Division & $16 / 218 \times 141=$ & 10 \\
\hline 8 & Procurement Planning Division & $7 / 218 \times 141=$ & 5 \\
\hline & $\quad$ Total & $\mathbf{2 1 8}$ & $\mathbf{1 4 1}$ \\
\hline
\end{tabular}

Data analysis in this study was carried out using the SPSS 16.0 application. This application was chosen because it is in accordance with the needs of the researcher as well as the ease in the procedures for operating it. Data analysis in this study began with descriptive analysis, analysis requirements test, and hypothesis testing using regression analysis.

\section{Results and Discussion}

In this study path analysis is divided into two sub-structures, namely: (1) Substructure I analyze the influence of organizational justice and trust in superiors as exogenous variables on job satisfaction as endogenous variables. (2) Substructure II analyzes the influence of organizational justice, trust in superiors and job satisfaction as exogenous variables on employee performance as endogenous variables. 


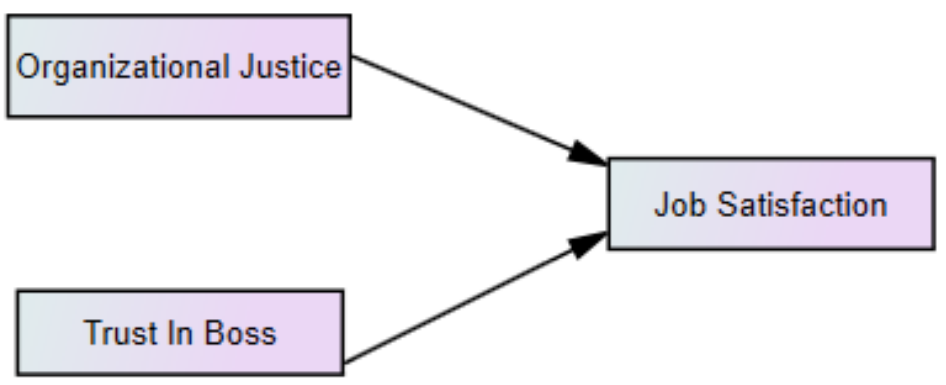

Figure 1 Substruktur I

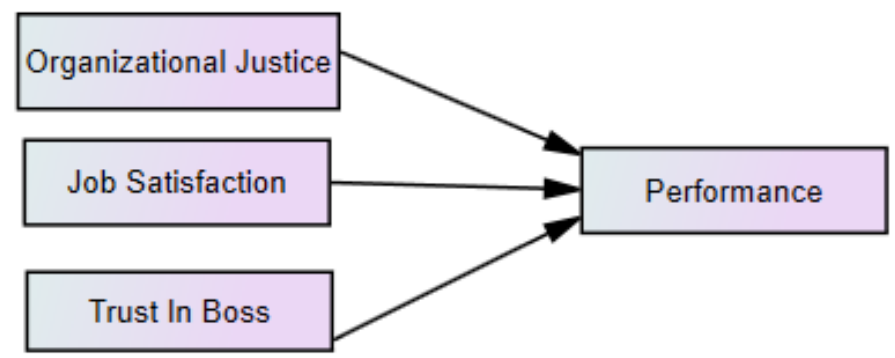

Figure 2 Substructur II

Based on analysis of substructure I and substructure II, a chart of path analysis results can be drawn drawn as follows:

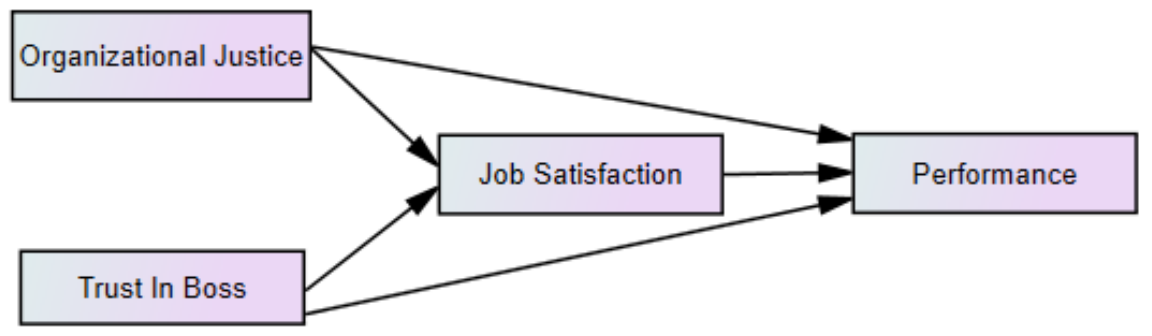

Figure 3 Result Path Analysist 
Tabel 2 Result of the Effects of Direct and Indirect Variable

\begin{tabular}{|c|c|c|c|c|c|c|}
\hline Numb & & iabe & & $\begin{array}{c}\text { Sifat } \\
\text { Pengaruh }\end{array}$ & $\begin{array}{l}\text { Pengaruh } \\
(\%)\end{array}$ & $\begin{array}{c}\text { Total } \\
\text { pengaruh } \\
(\%)\end{array}$ \\
\hline 1 & $\begin{array}{l}\text { Organizational } \\
\text { Justice }\end{array}$ & $\rightarrow$ & $\begin{array}{c}\text { Job } \\
\text { Satisfaction }\end{array}$ & Direct & $3,9 \%$ & \multirow{5}{*}{$86,8 \%$} \\
\hline 2 & Trust in Boss & $\rightarrow$ & $\begin{array}{c}\text { Job } \\
\text { Satisfaction }\end{array}$ & Direct & $34,6 \%$ & \\
\hline 3 & $\begin{array}{l}\text { Organizational } \\
\text { Justice }\end{array}$ & $\rightarrow$ & Performance & Direct & $2,1 \%$ & \\
\hline 4 & Trust in Boss & $\rightarrow$ & Performance & Direct & $3,7 \%$ & \\
\hline 5 & Job Satisfaction & $\rightarrow$ & Performance & Direct & $42,5 \%$ & \\
\hline 6 & \multicolumn{3}{|c|}{ Organizational Justice $\rightarrow$ Job } & Indirect & $1,8 \%$ & \multirow{2}{*}{$9,2 \%$} \\
\hline \multirow[t]{4}{*}{7} & \multicolumn{3}{|c|}{$\begin{array}{l}\text { Trust in Boss } \rightarrow \text { Job Satisfaction } \rightarrow \\
\text { Performance }\end{array}$} & Indirect & $7,4 \%$ & \\
\hline & \multicolumn{3}{|c|}{ Total Effect Research Variable } & & & $96 \%$ \\
\hline & \multicolumn{3}{|c|}{ Effect Another Variable } & & & $4 \%$ \\
\hline & Total & & & & & $100 \%$ \\
\hline
\end{tabular}

Based on figure 3 the percentage of direct and indirect effects of the above research variables on employee performance is presented in Table 2. the direct effect has a total effect of $86.8 \%$ from $96 \%$ total effect and direct effect just has a $9.2 \%$ effect and another variable has $4 \%$ effect.

Direct Effect

Table 3 Result the Relation between Variable

\begin{tabular}{lll}
\hline Hipotesis & $\begin{array}{l}\text { Koefisien } \\
\text { Path }\end{array}$ & Probability \\
\hline H1 Organizational $\rightarrow$ Job Satisfaction Justice & 0.198 & 0.003 \\
\hline H2 Trust in Boss $\rightarrow$ Job Satisfaction & 0.589 & 0.000 \\
\hline H3 Organizational Justice $\rightarrow$ Performance & 0.147 & 0.015 \\
\hline H4 Trust In Boss $\rightarrow$ Performance & 0.194 & 0.001 \\
\hline H5 Job Satisfaction $\rightarrow$ Performance & 0.652 & 0.000 \\
\hline
\end{tabular}

Based on Result The path coefficient of the influence of organizational justice on employee performance is 0.198 and is positive. This means that the higher organizational justice, the job satisfaction of employees will increase. This is contrary to the research conducted by Al-Zu'bi (2010) which states positive relationships with organizations and job satisfaction. Research conducted by Fatimah, et al (2011) shows a significant relationship between organizational justice and job satisfaction.

The results of hypothesis in Table 2 testing explain that what is found in this study and the theoretical concepts that support research, the influence of Trust in Boss on Job Satisfaction is 0.589 an is positive,in line with the results of previous studies conducted by Siddiqi and Kharshiing (2015) show that when employees trust their organization, they are more satisfied with their work. Trust is important for employee empowerment which in turn results in greater job satisfaction. The research findings of Meral et al. (2016) state that trust positively influences job satisfaction. And so on the results of hypothesis in Table 2 This finding the influence of Organizational Justice on Performance is 0.147 and is positive, this result in line with the research conducted by Iqbal, et al (2017) stating that organizational justice has a 
positive and significant effect on employee performance. The results of different studies found by Mahdani, et al (2017) organizational justice have a significant effect on the mediating variables of job satisfaction, but do not affect the employee performance variables.

Research findings indicate that trust in Boss has a significant effect on the performance of employees of PT. PLN (Persero) Main Unit of West Sumatra Region. Based on path analysis it is known that the regression coefficient is positive at 0.194 with a significance level of $0.001<0.05$. The results of this study are in line with the results of research by Widjajani, et al (2017) stating that trust has a significant influence on Employee Performance. But different with research Arief, et al (2018) which states that trust in leadership does not have a significant effect on employee performance.

The results of testing the fifth hypothesis in this study indicate that job satisfaction has a significant effect on the performance of employees of PT. PLN (Persero) Main Unit of West Sumatra Region. Based on path analysis obtained standardized regression coefficient of 0.652 with a significance level of 0.000 $<0.05$. The results of the study are in line with the theory of Robbins and Judge (2014: 113) stating that organizations that have more satisfied employees tend to be more effective than organizations that have employees who are less satisfied. Whereas according to the same thing also stated by Davis and Newstroom in Sinambela (2016), suggesting that some managers assume that high job satisfaction will forever lead to high achievement. Employee performance greatly impacts the maximum performance of the company. That is what causes employee job satisfaction is considered very important specially to support the company's performance in competition in this era of globalization (Wijaya \& Sutanto, 2014: $.2)$.

Indirect Effect

Table 4 Result of Indirect Effect between variable

\begin{tabular}{lc}
\hline \multicolumn{1}{c}{ Variable } & \% Influence \\
\hline Organizational Justice $\rightarrow$ Job Satisfaction $\rightarrow$ Performance & 1.8 \\
\hline Trust In Boss $\rightarrow$ Job Satisfaction $\rightarrow$ Performance & 7.4 \\
\hline
\end{tabular}

The effect of organizational justice on employee performance through job satisfaction as an intervening variable at PT. The PLN (Persero) Main Unit of the West Sumatra Region in this study was found to be $1.8 \%$. Previously it was found that organizational justice directly had an influence on employee performance. So that in the relationship between organizational justice and employee performance there is job satisfaction as an intervening variable. Increasing organizational justice can increase job satisfaction so that employee performance increases as well. The results of this study are in line with the research of Atmojo and Tjahjono (2016) which states that there is a mediating role of satisfaction with the influence of distributive justice on paramedic performance in hospitals. Other research conducted by Suharyoko (2016) states that there is a complete mediation effect of employee job satisfaction on procedural justice and distributive justice in influencing employee performance.

The effect of trust in Boss on employee performance through job satisfaction as an intervening variable at PT. The PLN (Persero) Main Unit of the West Sumatra Region in this study was found to be $7.4 \%$. Previously it was found that direct trust in Boss had an influence on employee performance. So that in the relationship between trust in Boss and employee performance there is job satisfaction as an intervening variable. Increased trust in Boss can increase job satisfaction so that employee performance increases as well. This research is supported by the results of research by Siddiqi and Kharshiing (2015) which show that when employees trust their organization, they are more satisfied with their work. This result is also supported by Jain's research (2014) which states that trust positively influences employee performance, and it has an impact on job satisfaction on employee performance. 


\section{Conclusion}

Based on the results of research on the influence of organizational justice, trust in superiors and job satisfaction on the performance of employees of PT. PLN (Persero) Main Unit of West Sumatra Region, conclusions can be drawn as follows:

Based on hypothesis Organizational justice has a significant effect on job satisfaction of employees of PT. PLN (Persero) Main Unit of West Sumatra Region. The path coefficient of the influence of organizational justice is 0.198 and is positive. This means that the higher organizational justice, the job satisfaction of employees will increase.

Trust in Boss has a significant influence on job satisfaction of employees of PT. PLN (Persero) Main Unit of West Sumatra Region with a positive path coefficient of 0.589 . This means that whenever there is an increase in trust in Boss, then it will be able to increase job satisfaction of employees of PT. PLN (Persero) Main Unit of West Sumatra Region.

Organizational justice has a positive and significant direct effect on employee performance. This means that high organizational justice will tend to improve employee performance. The higher organizational justice, the employee's performance will increase.

Trust in Boss has a positive and significant direct effect on employee performance. This means that the higher the trust in the boss both in terms of the competencies possessed by Boss, the virtues performed on employees, and the integrity of Boss at work, then it is able to contribute well to improving employee performance.

Job satisfaction provides a significant and positive influence on employee performance. This means that the higher employee job satisfaction, the higher the employee's performance, on the contrary the lower the employee's job satisfaction, the lower the employee's performance.

Then indirect effect between organizational justice on employee performance through job satisfaction as an intervening variable is $1.8 \%$. So that in the relationship between organizational justice and employee performance there is job satisfaction as an intervening variable. This means that high organizational justice can improve employee job satisfaction which has an impact on employee performance.

Same with organizational justice on employee performance, The influence of trust in boss on employee performance through job satisfaction as an intervening variable is $7.4 \%$. So that in the relationship between trust in Boss and employee performance there is job satisfaction as an intervening variable. This means that increased trust in Boss can increase employee job satisfaction so that employee performance increases as well.

\section{Suggestion}

1. Improve the performance of employees of the PLN (Persero) Unit of the West Sumatra Region through optimization of contextual performance (contextual performance) because there are still employees who are unable to separate the problem of the office with personal problems, increase cooperation between employees in work, and be able to provide support and motivation coworkers who are experiencing problems.

2. Improving organizational justice, especially in distributive justice by distributing a fair work schedule to all employees, adjusting payroll to positions, giving awards for employee work performance fairly so that employees feel valued so that employees of PT. PLN (Persero) The West Sumatra Region Master Unit works better.

3. PT. PLN (Persero) Main Unit of West Sumatra Region is advised to pay more attention to supervisor integrity by increasing the sense of justice given by Boss, instilling values that can build employee performance, and increasing consistency between actions and behavior of superiors at work. 
4. PT. PLN (Persero) West Sumatra Region Main Unit is advised to pay more attention to job satisfaction, especially to colleagues who support by helping employees work together, want to discuss work issues, and improve cooperation in work to make employee work results more optimal.

5. The results of the study show that the direct effect of organizational justice variables on employee performance has the lowest coefficient value. For this reason, PT. PLN (Persero) The West Sumatra Region Master Unit pays more attention to this variable in order to improve employee performance.

\section{References}

Adigun A. O., Oyekunle I. A and Onifade T. A. (2017). Influence Of Job Satisfaction On Employees' Performance In MTN Nigeria. Global Journal of Human Resource Management, 5(5),54-60.

Alvi, A. K., \& Abbasi, A. S. (2012). Impact of Organizational Justice on Employee Engagement in Banking Sector of Pakistan. Middle-East Journal of Scientific Research, 12(5), 643-649.

Al-Zu'bi, H.A. (2010). A Study Of Relationship Between Organizational Justice And Job Satisfaction. International Journal of Business and Management, 5(12), 102 - 109.

Atosokhi, A. (2014). Integritas Personal dan Kepemimpinan Etis. Jurnal Humaniora, 5(2), 950-959.

Bakhshi, Arti, Kuldeep Kumar dan Ekta Rani. (2009). Organizational Justice Perception As Predictor Of Job Satisfaction And Organization Comitment. International Journal of Business and Management, 4 (9), 145-154.

Becerra, E. P., \&Korgaonkar, P. K. (2011). Effects of trust beliefs on consumers' online intentions. European Journal of Marketing, 45, 936-962.

Burhan, Bungin. (2013). Metode Penelitian Sosial \& Ekonomi: Format-Format Kuantitatif Dan Kualitatif Untuk Studi Sosiologi, Kebijakan, Publik, Komunikasi, Manajemen, Dan Pemasaran Edisi Pertama. Jakarta: Kencana Prenada Media Goup.

Colquit, Le Pine, Wesson. (2009). Organizational Behavior. New York: Mc Graw Hill.

Fadlallh, Abdul, W, A. (2015). Impact of Job Satisfaction on Employees Performance an Application on Faculty of Science and Humanity Studies University of Salman Bin Abdul-Aziz-Al Aflaj. International Journal of Innovation and Research in Educational Sciences, 2(1), 2349-5219.

Fatimah, O., Amiraa, A M, and Halim F W. (2011). The Relantionship between Organizational justice, Organizational Citizenship Behavior and Job Satisfaction. Pertanika J. Soc. Sci \& Hum, 9,115-121.

Hasibuan, Malayu. (2014). Manajemen, Dasar Pengertian dan Masalah. Jakarta: Bumi Aksara.

Hidayah, S dan Haryani. (2013). Pengaruh Keadilan Distributif Dan Keadilan Prosedural Terhadap Kinerja Karyawan BMT Hudatama Semarang. Jurnal Ekonomi Manajemen Akuntansi. (35), 1-15.

Ibrahim, Mohamed E. dan Ann O. Perez. (2014). Effects of organizational justice, employee satisfaction, and gender on employees' commitment: evidence from the UAE. International Journal of Business and Management. 9(2), 45-59.

Indrayani, Cahya, L. P., dan Suwandana, Made, I, G. (2016). Pengaruh Keadilan Organisasional Terhadap Kepuasan Kerja Dan Komitmen Organisasional Pada Karyawan. E-Jurnal Manajemen Unud, 5(6), 3589-3619.

Iqbal, Muhammad, Z., Rehan, Muhammad., Anum, Fatima., dan Samina, Nawab. (2017). The Impact of Organizational Justice on Employee Performance in Public Sector Organization of Pakistan. International Journal of Economics \& Management Sciences. 6(3).

Jain, Ajay K. (2014). The Mediating Role Of Job Satisfaction In The Relationship Of Vertical Trust And Distributed Leadership In Health Care Context. Journal of Modelling in Management, 11 (2).

Kalay, Faruk. (2016). The Impact of Organizational Justice on Employee Performance: A Survey in Turkey and Turkish Context. International Journal of Human Resource Studies, 6(1), 2162-3058. 
Kreitner, Robert and Angelo Kinicki. (2014). Perilaku Organisasi, Edisi 9. Buku 1. Jakarta: Salemba Empat.

Kristanto, H. (2015). Keadilan Organisasional, Komitmen Organisasional dan Kinerja Karyawan. Jurnal Manajemen dan Kewirausahaan.17 (1), 86-98.

Krot, Katarzyna \& Lewicka, Dagmara. (2012). The Importance Of Trust In Manager-Employee Relationships. International Journal of Electronic Business Management, 10(3), 224-233

Lotfi, Mohammad Hosein dan Mohammad Shirazi Pour. 2013. The relationship between organizational justice and job satisfaction among the employees of Tehran Payame Noor University. Procedia Social and Behavioral Sciences. 93, 2073 - 2079.

Mahdani, Fonna., Hafasnuddin, Muhammad, Adam. (2017). Pengaruh Motivasi, Kecerdasan Emosional dan Keadilan Organisasi Terhadap Kepuasan Kerja Serta Implikasinya pada Kinerja Karyawan (studi pada kanwil PT. Bank Rakyat Indonesia (Persero) Tbk. Banda Aceh). Jurnal Magister Manajemen. 1(1).

Mai Ngoc Khuong. (2016). The Effects of Organizational Justice and Ethical Leadership on Employee Performance in Binh Duong's Industrial Parks, Vietnam. Journal of Economics, Business and Management, 4(4).

Mangkunegara, Anwar, P., (2014). Manajemen Sumber Daya Manusia Perusahaan. Bandung: PT. Remaja Rosdakarya.

Mangkuprawira, TB.S dan Hubeis., A.V. (2007). Manajemen Mutu Sumber Daya Manusia. Bogor. Ghalia Indonesia.

Maria, D. (2012). Connection between Job Motivation, Job Satisfaction and Work Performance in Romanian Trade Enterprises. Annals of "Dunarea de Jos" University of Galati Fascicle I. Economics and Applied Informatics, 18(3), 1-6.

Meral, Yurdagül ., Murat, Yaşlığlu, Fatih, Semerciöz. (2016). Effects of Trust on Job Satisfaction and Mediatory Role of New Identification between Trust and Job Satisfaction in Mergers. International Journal of Managerial Studies and Research (IJMSR), 4(5), 54-67.

Moeheriono. (2014). Pengukuran Kinerja Berbasis Kompetensi. Bogor : Penerbit. Ghalia Indonesia.

Mohsin, A., Hasan, A, Khasif, H., \& Muhammad, J. 2011. Empirical analysis of organizational justice towards employees customer oriented behaviour: A case study of medical institution in Pakistan. African Journal of Business Management, 5(4), 1286-1292.

Naeem, Ayesha T., Freeha Ihsan dan Zahid Mahmood. (2014). The Study Of Organizational Justice, Violation Of Psychological Contract And Its Effect On Job Satisfaction In Paints Industry Of Pakistan. International Journal of Academic Research in Business and Social Sciences. 4(12), 244-251.

Nkrumah, Gordon Abekah dan Atinga, Roger Ayimbillah (2013). Exploring The Link Between Organisational Justice And Job Satisfaction And Performance In Ghanaian Hospitals: Do Demographic Factors Play A Mediating Role?. International Journal of Workplace Health Management, 6 (3), 189-204.

Orebiyi, A. O., (2011). The Influence of Interpersonal Communication on Secondary School Teachers' Job Satisfaction and Three Types of Commitments in Kogi State, Nigeria. Journal of Communication and Culture: International Perspective. 2(1), 109-117

Prasetyo, Arief, Y., Sularso, Andi., dan Handriyono. (2018). Pengaruh Kepercayaan Pada Pimpinan, Mutasi Dan Budaya Organisasi Terhadap Motivasi Kerja Dan Kinerja Pegawai di Badan Pendapatan Daerah Kabupaten Jember. Bisma Jurnal Bisnis dan Manajemen, 12(2), 182 - 190.

Priansa, Donni Juni. (2014). Perencanaan dan Pengembangan Sumber Daya Manusia. Bandung: Alfabeta. Priyatno, Duwi . (2010). Paham Analisa Statistik Data SPSS. PT Buku Seru, Yogyakarta.

Qatmeemalmarhoon, Ahmed, B, A, S, Mohdnoor, Khairrunneezam B., Marai, A. D, Abdalla, dan MUSBAH, A, R. (2017). Effect Of Motivation On Employees' Performance And Employees' Commitment. International Journal of Management and Applied Science, 3(9) 
Ratnawati. (2013). Pengaruh Keadilan Organisasional, Kepercayaan Pada Atasan Terhadap Perilaku Kewargaan Organisasi (Organizational Citizenship Behavior). Jurnal Ekonomi Manajemen Dan Bisnis. 1(1), 56-73.

Retno, W., Dwi, D.,\& Heru, S. (2014). Hubungan Antara Keadilan Organisasi Dengan Perilaku Anggota Organisasi Pegawai Tata Usaha SMA Negeri Kota Jakarta Utara. Improvement jurnal: Jurnal Ilmiah Untuk Meningkatkan Mutu Pendidikan.

Riduwan and Akdon. (2009). Aplikasi Statistika dan Metode Penelitian untuk. Administrasi dan Manajemen. Bandung: Dewa Ruci.

Robbin, Stephen P \& Judge Timothy A. (2014). Perilaku Organisasi Jilid 2. Jakarta: Salemba Empat. Robbins, Stephen P, Judge, Timothy A. (2015). Organizational behavior. United State of America: Pearson.

Salwa, Arfah., Yuwaldi, Away., dan Mirza,Tabrani. (2018). Pengaruh Komitmen, Integritas Dan Kompetensi Terhadap Kinerja Pegawai Serta Dampaknya Pada Kinerja Komisi Independen Pemilihan (KIP) Aceh. Jurnal Magister Manajemen, 2(1).

Sari, Diana, P., Tjahjono, Heru K., \& Fauziyah. (2016). Pengaruh Keadilan Distributif Rotasi Kerja Dan Keadilan Prosedural Rotasi Kerja Terhadap Kepuasan Kerja yang Berdampak Pada Kinerja Karyawan (Studi Kasus Pada PT. Panpages Yogyakarta). Prosiding Konferensi Nasional Ke-3. ISBN: 978-602-19568-0-9.

Sethi, M \& Hina Iqbal. (2013). "Relationship between Perceived Organizational Justice and the Employees Job Satisfaction". Abasyn Journal of Social Sciences. 7(1).

Siddiqi, Nasrina., Kharshiing, Korsi, D. (2015). Influence of organizational trust on job satisfaction and organizational commitment. Abhigyan, XXXIII(2).

Sinambela, Lijan Poltak. (2016). Manajemen Sumber Daya Manusia. Jakarta: PT Bumi Aksara.

Sopiah. (2008). Perilaku Organisasional. Yogyakarta: Penerbit Andi.

Sugiyono. (2014). Metode Penelitian Pendidikan,(Pendekatan Kuantitatif, Kualitatif, dan RED). Bandung: Alfabeta.

Suharyoko. (2016). Pengaruh Keadilan Distributif Dan Prosedural Terhadap Kinerja Pegawai Dengan Kepuasan Kerja Sebagai Variabel Intervening (Studi pada Pegawai Palang Merah Indonesia Eks Karesidenan Surakarta). Jurnal Widya Ganeswara, 26 (1).

Sunyoto, Danang. (2012). Teori, Kuesioner dan Analisis Sumber Daya Menusia. Yogyakarta: PT Buku Seru.

Susanj, Z \& Ana Jakopec, (2012). "Fairness Perceptions and Job Satisfaction as Mediators of the Relationship between Leadership Style and Organizational Commitment". Psychological Topics 21(3), 509- 526.

Sutrisna, I Wayan Wira \& Agoes Ganesha Rahyuda. (2014). Pengaruh Keadilan Distributif, Prosedural, Dan Interaksional Terhadap Kepuasan Kerja Dan Komitmen Organisasi Pada Paramedis Di Rumah Sakit Tk II Udayana Denpasar. E-Jurnal Manajemen Universitas Udayana. Vol. 3. No. 9. pp. $2489-2509$.

Wijaya, F. J. \& Sutanto, E. M. (2014). Pengaruh komitmen organisasional dan kepuasan kerja karyawan terhadap organizational citizenship behavior di PT XYZ Surabaya. Agora. 2(2).

Yulianti, Eli. (2015). Pengaruh Pelatihan Terhadap Kinerja Karyawan Grand Fatma Hotel Di Tenggorong Kutai Kartanegara. Jurnal Administrasi Bisnis.ISSN 2355-5408. 